\title{
Assessment of the dynamics of the Volta river estuary shorelines in Ghana
}

\author{
K. Appeaning Addo ${ }^{*}$, E. K. Brempong and P. N. Jayson-Quashigah
}

\begin{abstract}
Estuarine shorelines similar to marine coastlines are highly dynamic and may increase disaster risk in vulnerable communities. The situation is expected to worsen with climate change impacts and increasing anthropogenic activities such as upstream water management. This study assessed shoreline changing trends along the Volta river estuary in Ghana as well as the marine coastline using satellite imageries, orthophotos and topographic maps spanning a period of 120 years (1895, 1990, 2000, 2005 and 2015). Linear regression method in the Digital Shoreline Analysis System (DSAS) was used to determine the estuary shoreline migration trend by estimating the shorelines rate of change for the eastern and western sides of the estuary. The rates of change of the marine coastlines on the east and west of the estuary were also estimated. The results show that the eastern and western shoreline of the estuary are eroding at an average rate of about $1.94 \mathrm{~m} / \mathrm{yr}$ and $0.58 \mathrm{~m} / \mathrm{yr}$ respectively. The coastlines on the marine side (eastern and western) are eroding at an average rate of about $2.19 \mathrm{~m} / \mathrm{yr}$ and $0.62 \mathrm{~m} / \mathrm{yr}$ respectively. Relatively high rates of erosion observed on the eastern estuarine shoreline as well as the coastline could be explained by the reduced sediment supply by the Volta River due to the damming of the Volta River in Akosombo and the sea defence structures constructed to manage erosion problems. The trend is expected to increase under changing oceanographic conditions and increased subsidence in the Volta delta. Effective management approach, such as developing disaster risk reduction strategy, should be adopted to increase the resilience of the communities along the estuarine shoreline and increase their adaptive capacity to climate change hazards and disasters.
\end{abstract}

Keywords: Coastal erosion, Volta estuary, Shoreline change, Disaster risk, Vulnerability

\section{Introduction}

Estuarine shorelines are naturally dynamic and continuously shaped by natural and anthropogenic factors (Bio et al. 2015; Appeaning Addo et al. 2008; Jayson-Quashigah et al. 2019). These factors combine to increase pressure on the estuarine systems, the coastal environment and coastal cities. Climate change induced oceanographic conditions (including sea level rise) is expected to increase coastal erosion and flooding hazards associated with estuarine shoreline dynamics (Arthurton et al. 2000). This will affect the ecosystem services the estuaries provide and increase the risk of exposure to these hazards in vulnerable

\footnotetext{
* Correspondence: kappeaningaddo@ug.edu.gh

Department of Marine and Fisheries Sciences, College of Basic and Applied Sciences, University of Ghana, P. O. Box Lg 99, Legon, Accra, Ghana
}

communities along the estuary shorelines. The risk level will be high in vulnerable coastal communities and cities in developing nations where there is paucity of data and early warning systems are limited. Developing disaster risk reduction strategies for vulnerable communities will require understanding into the levels of vulnerability and the factors that increase the hazards. Disaster risk reduction reflects the systematic development and application of policies, strategies and practices to minimize vulnerabilities, hazards and the unfolding disaster impacts (Mercer et al. 2010). It is significant to understand the dynamics of the drivers of hazards and how they influence risk in vulnerable communities, especially in developing countries where adaptation options are limited. Various methods have been developed to monitor the evolution trend of the biophysical drivers of hazards and determine how they 
combine to increase risk in vulnerable communities (Appeaning Addo et al. 2008; Graham et al. 2003; Leatherman et al. 2005).

Monitoring the geometry of the estuarine shoreline morphology is key to understanding the evolution trend in the estuarine shoreline position over time and how it impacts the environment (Oyedotun 2014). It also reveals how estuarine shorelines are responding to climatic and anthropogenic induced stressors that have the potential to result in environmental hazards. Geographical Information Systems (GIS) and Remote Sensing approach in mapping high erosion risk zones have increased accuracy in feature identification, feature extraction and change detection in coastal zones significantly (Natesan et al. 2015; Kannan et al. 2016; Van and Binh 2008). They also help in collecting data from inaccessible and rapidly changing or hazardous environment (Wiafe et al. 2013). Such information is relevant in effective management of resources in vulnerable areas within the coastal environment as well as developing a framework for disaster management. This paper presents results of Volta estuary shoreline morphological change assessment from 1895 to 2015 within the Volta delta region in Ghana. For this paper, shoreline will be used to represent the riverine side of the coast while coastline will be used to represent the marine side of the coast.

\section{The Volta delta}

The Volta River basin covers about $400,000 \mathrm{~km}^{2}$ (Van de Giesen et al. 2010). The river basin is a trans-national catchment shared by six riparian countries (Fig. 1). The watershed is $40 \%$ in Ghana, $42 \%$ in Burkina Faso, $6 \%$ in Togo, $5 \%$ in Mali, $4 \%$ in Benin and 3\% in Côte d'Ivoire (Oguntunde et al. 2006). The Volta River has three main tributaries namely the White Volta, the Black Volta and the Oti River (Ibrahim et al. 2016). It is one of the main sources of sediment supply to the Gulf of Guinea (Goussard and Ducrocq 2014). The river drains a predominantly sandstone catchment that also includes a wide variety of lithologic terranes covering an area of about $390,000 \mathrm{~km}^{2}$ (Anthony 2015). The Volta River presently has a single outlet channel to the sea at Ada, which is associated with a relatively large spit. The large spit is as result of a direct outgrowth of a natural change in the location of the mouth of the river (Anthony et al. 2016).

Located at the lower portion of the basin is the Volta delta, which is defined as the $5 \mathrm{~m}$ contour within the Accra-Ho-Keta Plains (Appeaning Addo et al. 2018). The geology is of the Volta Delta is generally Quaternary which is made up of alluvial sand, silt and clay (JaysonQuashigah et al. 2013). The delta coast is bounded by a narrow shelf $15-33 \mathrm{~km}$ wide, and characterised by a fairly uniform, moderately steep shoreface with a gradient of between 1:120 and 1:150 down to $15 \mathrm{~m}$, which is considered as the close-out depth for significant waveinduced sediment movement on this coast (Rossi 1989; Anthony 2015). The Volta River historically carried large quantities of sediment, including coarse-grained sand, to the sea and this sediment was deposited at the river mouth, forming the modern delta (Nairn et al. 1999).

The delta front is shaped by the action of the ocean waves, which is influenced by the nearshore bathymetry and the shoreline orientation. Unimpeded swell waves of moderate to high energy with an average height of about $1.4 \mathrm{~m}(\mathrm{~m})$ and a long period of about $11 \mathrm{~s}(\mathrm{~s})$ approach the shoreline from the south-south west (Almar et al. 2015; Angnuureng et al. 2016). The energy dissipated when the waves break generate longshore currents that transport sediment alongshore from west to east, which causes one of the highest rates of annual unidirectional longshore sediment drift in the world (1-1.5× $106 \mathrm{~m} 3 /$ yr) (Nairn et al. 1999). Tides are semi-diurnal with a tidal range of about $1 \mathrm{~m}$ and generate weak currents that have limited effect on the shoreline morphology (Appeaning Addo et al. 2008). Figure 2 shows the Volta delta and the $5 \mathrm{~m}$ contour delta boundary.

The Volta River's discharge varied between $1000 \mathrm{~m}^{3} / \mathrm{s}$ in the dry season and over $6000 \mathrm{~m}^{3} / \mathrm{s}$ in the wet season before the construction of the Akosombo Dam in 1964 (Anthony et al. 2016). Two other dams were constructed at Kpong in 1982 and Bui in 2013 (see Fig. 1), which have further affected the discharge rate. Runoff before the Akosombo dam construction was higher $(87.5 \mathrm{~mm} /$ yr) and more varied than the post-dam period with value of $73.5 \mathrm{~mm} / \mathrm{yr}$ (Oguntunde et al. 2006). Given that water flow is now controlled, the system dynamics in the estuary has also changed with regards to flow and sedimentation. The yearly sediment transport before the dam construction was about 7.5 million $\mathrm{m}^{3} / \mathrm{s}$ (Bollen et al. 2011). Since the construction of the Akosombo dam, there are no peaks in flow discharge and the sediment transport is reduced to only a fraction of the original transport (Bollen et al. 2011). This dramatic reduction in sediment supply to the delta system has affected the evolution of the delta and exacerbated coastal erosion in the deltaic region (Armah 1991; Allersma and Tilmans 1993). Erosion in the Volta Delta was first reported in 1929 but posited to have existed since the 1860s, particularly in Keta (Nairn et al. 1999). Ly (1981) estimated that the coastline in Keta (east of the estuary) was eroding at a rate between 4 and $8 \mathrm{~m} / \mathrm{yr}$, while Boller et al. (2011) reported that the coastline in Totope - Ada (west of the estuary) is receding at a rate of about $6 \mathrm{~m} / \mathrm{yr}$. Appeaning Addo (2015) identified significant changes in the coastline immediately to the east of the estuary and concluded that the hydrodynamics of the estuary could affect the estuary shorelines. The study estimated the mean erosion in the Volta delta coastline as $1.86 \mathrm{~m} / \mathrm{yr}$ (Appeaning Addo 2015). 


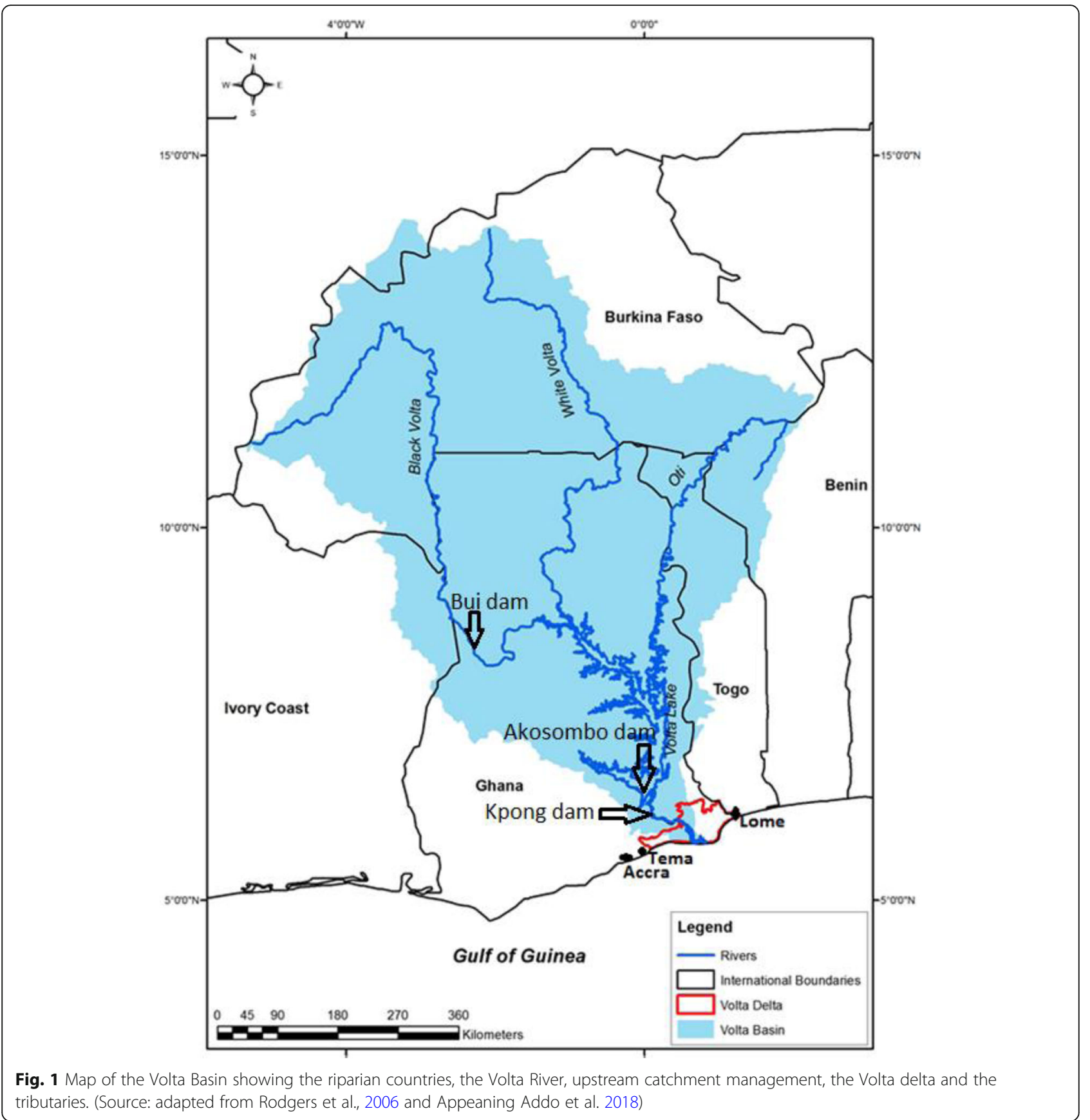

It is estimated that by 1996, more than half of Keta and its surrounding towns were under water due to increased rate of erosion and flooding (Ile et al., 2014), displacing about 500,000 people in communities within Keta and leading to losses in millions of Ghana Cedis (Danquah et al. 2014). The Keta and Ada Sea Defence Projects were undertaken by the Ghana government in 2001 and 2013 respectively to manage the impacts of erosion and flooding on the coastal communities. The Keta defence project included the construction of six groynes to prevent erosion and to control flooding of buildings between the Keta Lagoon and the sea, construction of a causeway across the Keta lagoon for the coastal highway, reclamation of lands lost to the sea and construction of houses for resettlement of displaced people (Boateng 2009; Danquah et al. 2014). Although the Keta sea defence project has been successful as beaches have been built and the artisanal fishing activities restored (Angnuureng et al. 2013), it has resulted in increased erosion on the down-drift side of the coast Appeaning Addo 2015; Wiafe et al. 2013; Angnuureng et al. 2013). The erosion problems has therefore been 


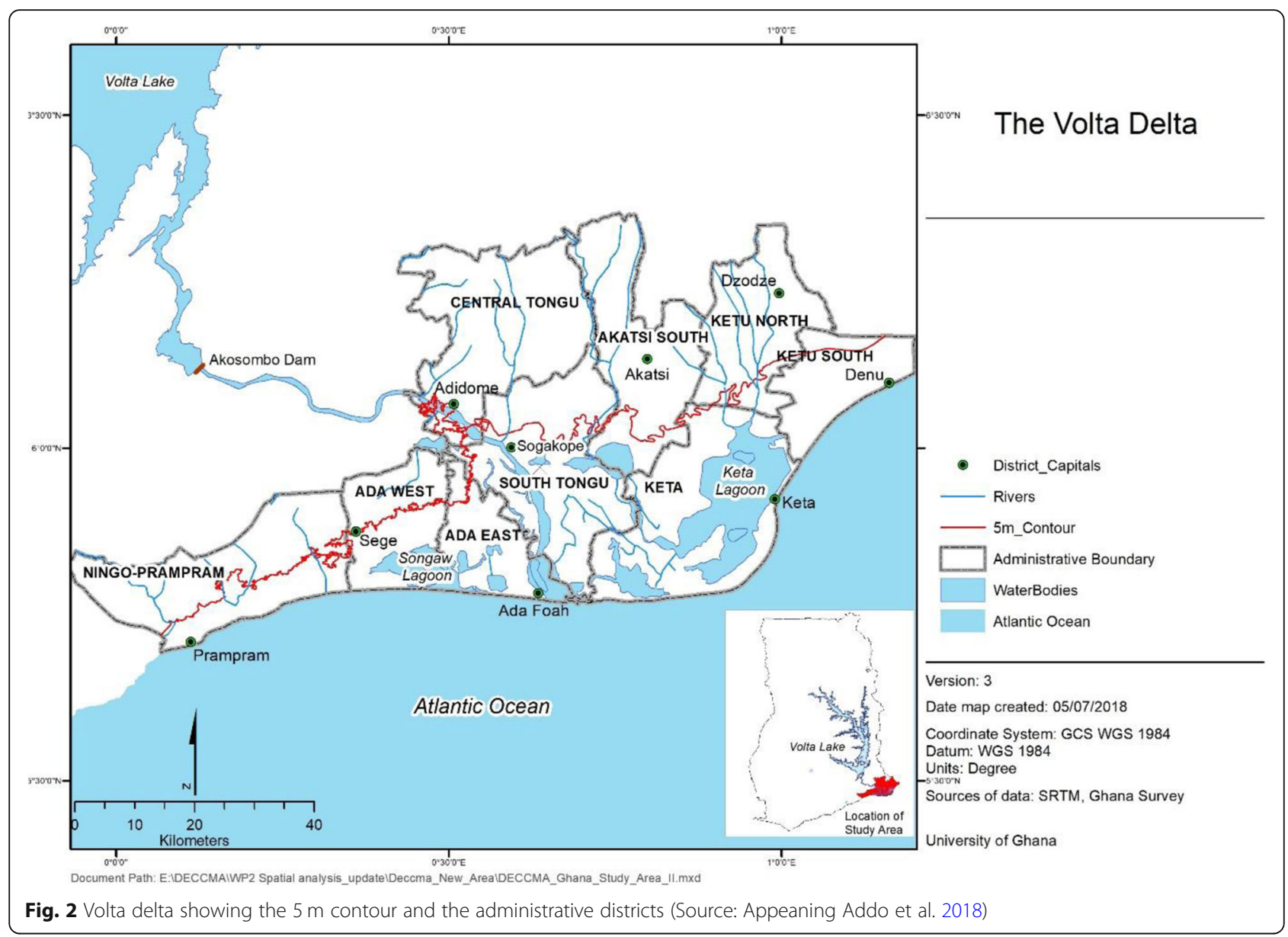

transferred to the eastern side of the coast which has resulted in destruction of properties and households sources of income (Angnuureng et al. 2013). The government has initiated another sea defence project along the eroding coast using groynes to manage the erosion and flooding problems as well as protect the vulnerable communities. Recent coastal erosion mitigation and adaptation measures along the Volta delta coast have been preceded by attempts by the communities to protect the coastline in Keta and its environs since 1923, which were not successful (Akyeampong 2001). The failures were because the materials used for the defence work could not withstand the strong waves (Akyeampong 2001; van der Linden et al. 2013). The government in 1960 undertook coastal protection project in Keta using steel sheets to protect about 1600 m of the Keta Township but these corroded not long after (van der Linden et al. 2013). Fig. 3 shows the impact of coastal erosion along the Volta delta coast in two highly vulnerable communities, Fuvemeh and Ada, which are experiencing varying intensity of erosion and flooding that has resulted in property destruction, loss of sources of livelihoods and displacement of households (Appeaning Addo et al. 2018).

\section{Methodology}

Materials for this study were obtained from various sources. They include satellite images (Landsat 1990, 2000 and 2005 pan sharpened to a resolution of $15 \mathrm{~m}$ ) obtained from United States Geological Survey (USGS) as well as historic (1895) and orthophoto (2015) maps obtained from the survey and mapping division of the Ghana Lands Commission. The data spanned a period of 120 years, which can be classified as long term. Figure 4 shows samples of orthophoto (2005) and satellite image (2015) respectively.

The estuarine shoreline positions and the marine coastlines were identified as the water-land boundary represented by the high water mark, and digitized in a GIS environment. The marine coastlines were about 15 $\mathrm{km}$ to the west and $10 \mathrm{~km}$ to the east of the estuary inlet. The shoreline and coastline rates of change were computed using the Digital Shoreline Analysis System (DSAS), an extension to ESRI ArcGIS. DSAS was developed to produce digital shoreline position data from historical maps, charts and photographs (Thieler et al. 2009). The extension contains three main components that define a baseline, generate orthogonal transects at a 

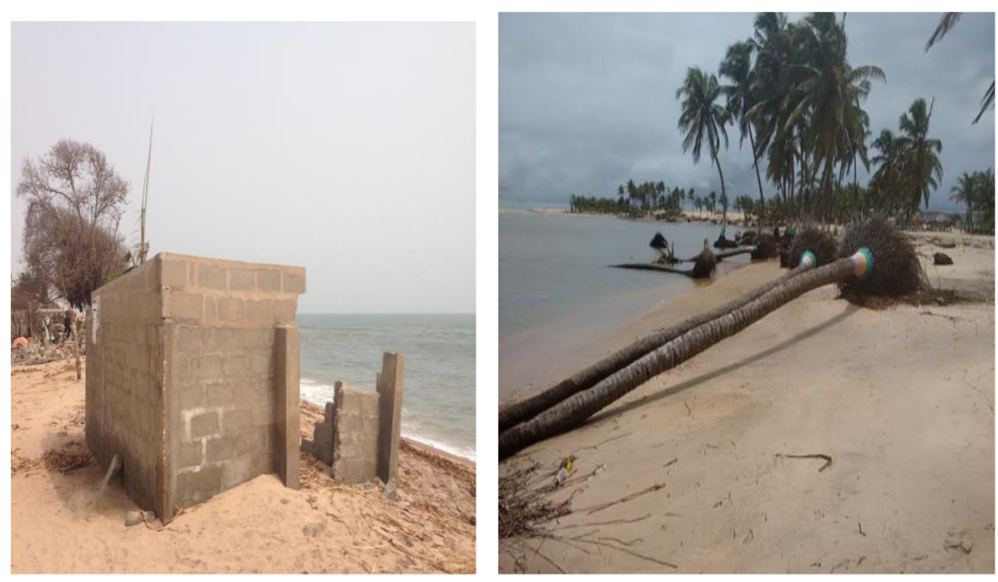

Fig. 3 Destruction at Fuveme and Ada due to increased erosion

user defined separation along the coast and calculate rates of change. It utilizes the avenue code to develop transects and rates, and uses the avenue programming environment to automate and customize the user interface (Morton et al. 2004). Shapefiles of the input data (shorelines) were managed in a personal geodatabase and appended to one shapefile for the rates of change estimation. A baseline, which served as the starting point for the rates computation was digitized offshore by mimicking the 1895 shoreline position and perpendicular transects cast at $50 \mathrm{~m}$ intervals. The $50 \mathrm{~m}$ intervals were selected to cover more areas to increase the accuracy in the rates computed (Appeaning Addo et al. 2008). A total of 1338 transects were cast along the coastline from east to west, 273 transects for the western estuarine shoreline and 211 transects for the eastern estuarine shoreline. Linear regression rate of change statistic method in DSAS was adopted for this study. Linear regression is robust, allows supplemental statistics to be computed and is efficient when a limited number of shorelines is available (Thieler et al. 2009). The average rate of changes (erosion and accretion) were computed for the all shorelines. Sources of uncertainty were identified and quantified. They include errors as a result of planetable survey used to generate the 1895 historic map; digitization of the estuarine shoreline and the coastline positions from both the satellite and the orthophoto maps; and photogrammetric error for developing the orthophoto maps. An overall shoreline positional error for each epoch (Ex) was therefore calculated using the following equation:

$$
E_{x}=\sqrt{E_{d}^{2}}+E_{p}^{2}+E_{p m}^{2}
$$

where $E_{d}$ is the error occurring from scale digitizing, $E p m$ is the photogrammetric error and $E p$ is the planetable survey error. This approach carries the assumption that component errors are normally distributed (Dar and Dar 2009).

The total uncertainties were used as weights in the shoreline change calculations. The values were annualized to provide error estimation for the shoreline change rate at any given transect and expressed as:

$$
E_{a}=\frac{\sqrt{ } E_{1}^{2}+E_{2}^{2}+E_{3}^{2}+E_{4}^{2}}{T}
$$

where $E_{1}, E_{2}, E_{3}$ and $E_{4}$ are the total shoreline position error for the various years and $T$ is the 120 years period of analysis.
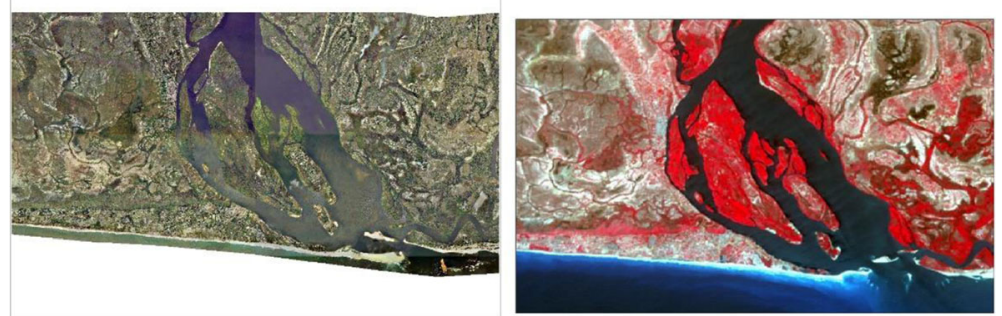

Fig. 4 Sample of 2005 Orthophoto and 2015 satellite imagery 


\section{Results}

Changing trend in the shoreline positions were observed for both the marine and estuarine sides, i.e. eastern and western, for the 120 year period. Figure 5 shows portions of the merged five shoreline positions for 1895, 1990, 2000, 2005, and 2015 along the coast. Figure 6 shows overlay of the cast perpendicular transect lines on the merged shoreline positions for the rates of change computation and Table 1 presents the rates of change computed for the various sections. Figure 7 is a graph of erosion and accretion trends along the coast, while Figs. 8 and 9 are graphs of evolution trend on the western and eastern estuarine sides respectively.

\section{Discussion}

The study has revealed the evolution trend along the estuary shoreline and the marine coastline in the Volta delta. These dynamic coastal morphological features are changing at varying rates and intensity. The biophysical changes are impacting the estuarine environment as well as the socioeconomic and cultural dynamics of people in the vulnerable coastal communities significantly. The Volta Delta has a diverse economic system with different but integrated sectors, i.e., agriculture including livestock rearing and fisheries, salt and sand mining, construction, trade, transport and tourism (Codjoe et al. 2017), which can be affected considerably by biophysical changes in the shoreline dynamics. The Volta delta coast has been identified as a very dynamic area that is experiencing erosion, flooding and shoreline recession (Ly 1980; Boateng 2009; Appeaning Addo 2015). Coastal erosion has impacted the vulnerable communities along the Volta delta coast that has resulted in destruction of properties, displacements of households and increased poverty significantly (Appeaning Addo et al. 2018). Within the period under study, the overall average rate of erosion on the marine coastline is about $0.79 \pm 0.24 \mathrm{~m} / \mathrm{yr}$ while the average rate of accretion is about $1.24 \pm 0.24 \mathrm{~m} / \mathrm{yr}$. The eastern part of the marine coastline is eroding at an average rate of about $2.19 \pm 0.24 \mathrm{~m} / \mathrm{yr}$ while the average rate of accretion is about $1.37 \pm 0.24 \mathrm{~m} / \mathrm{yr}$. The western side of the marine coastline is eroding at an average rate of about $0.62 \pm 0.242 \mathrm{~m} / \mathrm{yr}$ and the average rate of accretion is about $0.33 \pm 0.24 \mathrm{~m} / \mathrm{yr}$. On the other hand, the eastern estuarine side is eroding at an average rate of about $1.94 \pm 0.24 \mathrm{~m} / \mathrm{yr}$ while the rate of accretion is about $0.16 \pm 0.24 \mathrm{~m} /$ year. The western estuarine shoreline is eroding at an average rate of about $0.85 \pm 0.24 \mathrm{~m} /$ $\mathrm{yr}$ with an average rate of accretion of about $0.14 \pm 0.24$ $\mathrm{m} / \mathrm{yr}$. The coastal erosion hot spots identified include Ningo and Ada on the western coastline; and Keta, Akpletokor, Dzita, and Blekusu on the eastern coastline (Jayson-Quashigah et al. 2018). These locations are experiencing varying intensity of erosion that are affecting the environment and the communities significantly.

Results of this study confirm observations by Ly (1980), Appeaning Addo (2015) and Boateng (2012) who reported that the Volta delta marine coastline is an eroding coastline. Increased erosion along the coast is as a result of several factors such as controlled sediment discharge from the Volta River due to the construction of the Akosombo dam (Ly 1980); oceanographic conditions such as storm surge, energetic swell waves and subsidence; coastal erosion management structures and urbanisation (Boateng, 2009); and beach sand mining (Anim et al. 2013). Construction of the Akosombo dam has reduced the volume of sediment that flows into the ocean and resulted in sediment budget deficit (Appeaning
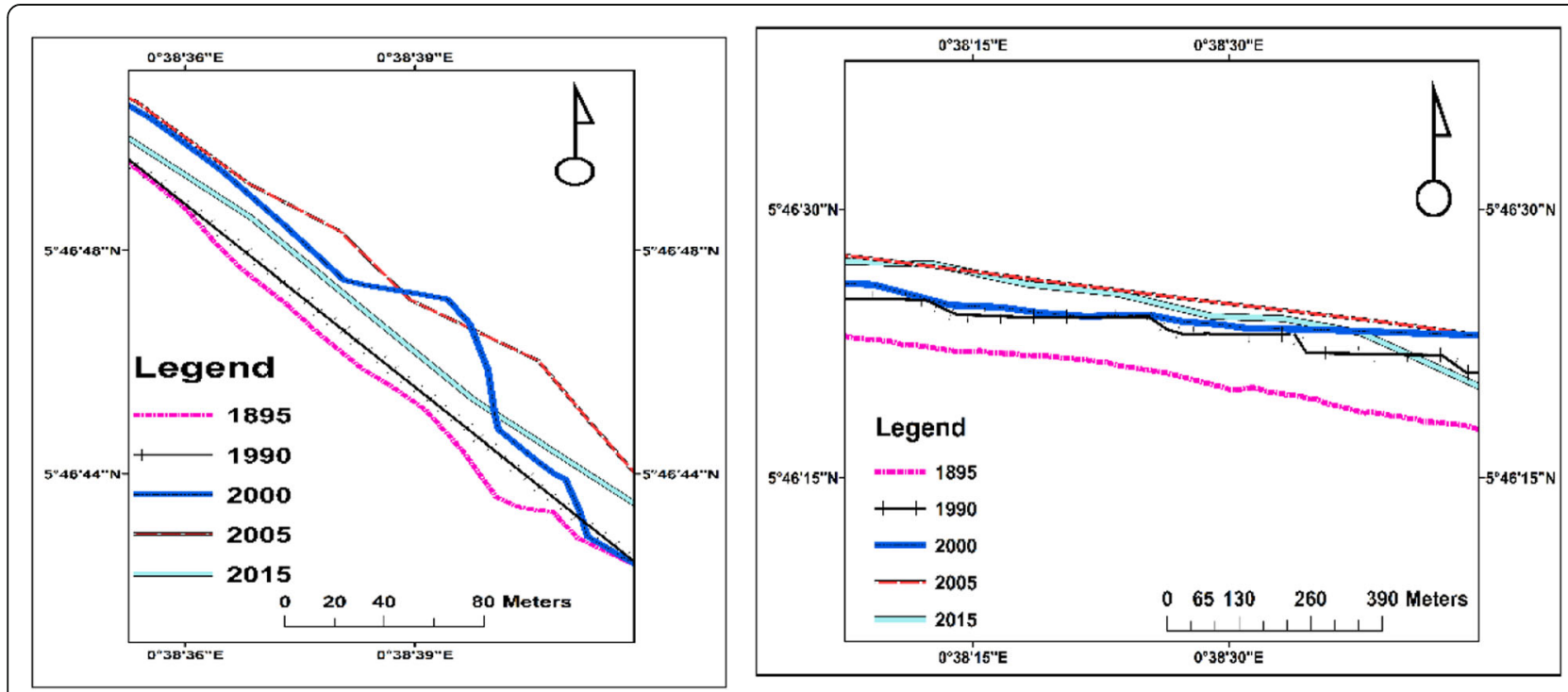

Fig. 5 Merged coastline positions on the marine side 


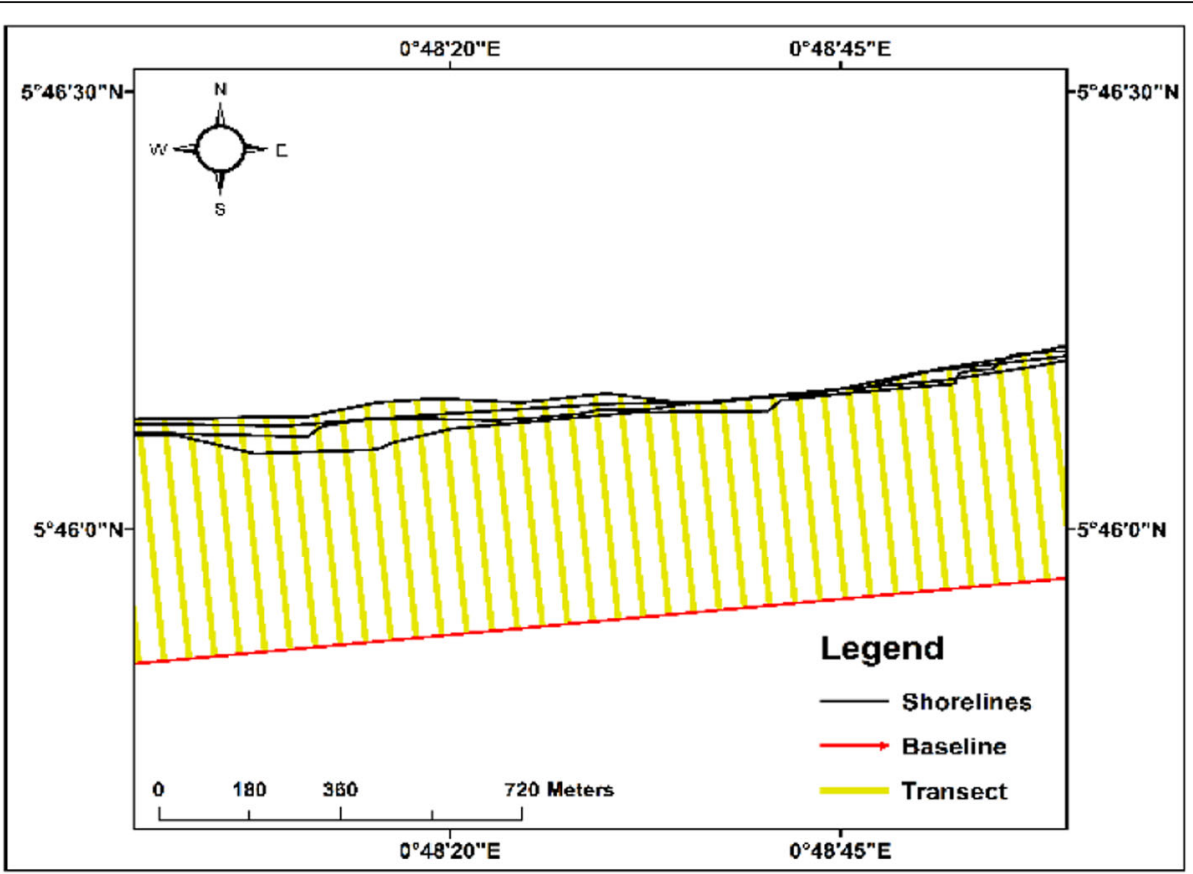

Fig. 6 Transects cast along the baselines and shorelines

Addo 2015). The shoreline erodes sediment from the coast to make up for the shortfall in sediment. The problem is further aggravated by the construction of sea defence structures to manage erosion in Keta and Ada using groynes. The groynes trap sediments that build beaches on the up-drift side while the down-drift side is starved of sediment that results in increased erosion (Angnuureng et al. 2013). Reduced sediment supply from the Volta river has also affected the evolution process of the delta, which has resulted in subsidence. Although the rate of subsidence has not been measured in the Volta delta, it is however suspected to be between $1 \mathrm{~mm} / \mathrm{yr}$ and $2 \mathrm{~mm} / \mathrm{yr}$ as experienced in most deltas globally (Appeaning Addo et al. 2018). Lowering of the delta topography as a result of water extraction for irrigated coastal crop farming facilitates erosion in the vulnerable areas as they enhance the natural subsidence (Ericson et al. 2006; Nicholls et al. 2016; Pont et al.

Table 1 Rates of change computed for the various sections

\begin{tabular}{lll}
\hline Shoreline change results & & \\
\hline Location & $\begin{array}{l}\text { Rate of Erosion } \\
(\mathrm{m} / \mathrm{yr} .)\end{array}$ & $\begin{array}{l}\text { Rate of Accretion } \\
(\mathrm{m} / \mathrm{yr} .)\end{array}$ \\
\hline Along the whole shore & -0.79 & 1.24 \\
Eastern coastline & -2.19 & 1.37 \\
Western coastline & -0.62 & 0.33 \\
East estuarine shoreline & -1.94 & - \\
West estuarine shoreline & -0.58 & 0.14 \\
Uncertainty (error) & & \pm 0.24 \\
\hline
\end{tabular}

2002; Syvitski et al. 2009). Although beach sand mining is banned in Ghana (Angnuureng et al. 2013), the practice is going on as the mined sand is the main construction material in the communities. The practice opens up the coast to ocean wave attacks that has the potential to initiate coastal erosion.

Increased oceanographic activities have been reported by Appeaning Addo et al. (2018) as a major cause of erosion and flooding in the coastal zone of the Volta delta. Increasing frequency in storm surge as a result of climate change and sea level rise enable the relatively high energetic swell waves to break closer to the shore dissipating their energy. The energy dissipated when the swell waves break at the shore generates longshore currents that transports sediments along shore. The coastal area of the Volta delta is considered as one of the highest rates of annual unidirectional longshore sediment drift in the world (Nairn et al. 1999) that results in significant morphological changes in the coastline position. Increasing population growth and urbanisation have altered the land cover, topography and land use in the delta region, thus, vegetated land has been converted to agricultural use and settlements (Appeaning Addo 2015). The population density of the Volta Delta is 151 persons per $\mathrm{km}^{2}$ compared to 103 persons per $\mathrm{km}^{2}$ in Ghana (Codjoe et al. 2017). Increasing urbanisation in the Volta delta will result in clearing the coastal vegetation for construction, which will reduce the natural protection the vegetation cover offer the coastal zone against erosion. 


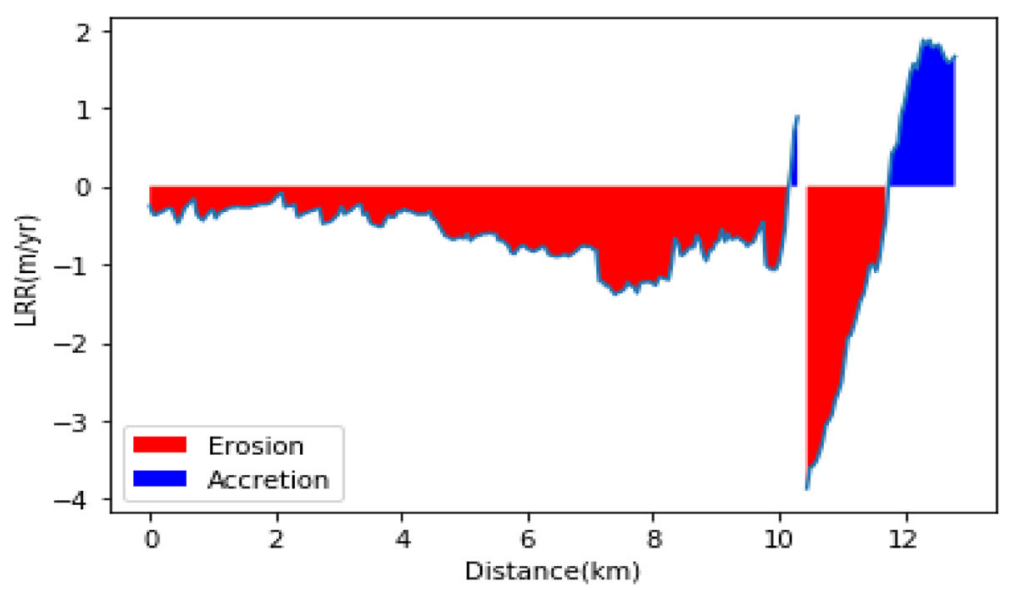

Fig. 7 Linear Regression Rate of Change along the marine side of estuary

Increased erosion in the estuarine shorelines and flooding in the coastal zone occur, particularly during spillage of the Akosombo dam in Ghana and the Bagre Hydro dam in Burkina Faso (Mumuni 2016; Logah et al. 2017). The Bagre dam, which is on the White Volta tributary of the Volta river, has water holding capacity of $235 \mathrm{~m}$ (Mumuni 2016). Extra water is let out once the holding capacity of the Bagre dam is reached to avoid breaking the banks of the dam. This increases the volume of water in the Akosombo dam downstream and results in spillage of the Akosombo dam. Spilling of excess water in the Akosombo dam causes flooding and erosion of vulnerable communities along the Volta river. According to WRC (2007), it results in loss of livelihoods and increased health risks of communities through the loss of agriculture and fishing activities and increases cases of malaria and urinary schistosomiasis, as well as appearance of intestinal schistosomiasis. The situation has increased poverty significantly and led to shift in income generating activities in the affected communities. It is estimated that about 80,000 people are directly adversely affected by the changed conditions in the Lower Volta Basin (Logah et al. 2017). The increasing exposure of the vulnerable communities to the erosion hazards has resulted in some of the households migrating to safer areas as an adaptation measure (Boateng 2009; Karley 2009; Lumor 2015).

Measures have been adopted by the Ghana government to manage erosion, which consist mainly of hard engineering approach using groynes and revetments (Nairn and Dibajnia 2004). Significant success has been achieved with the approaches adopted in the locations where the structures have been constructed (Jayson-Quashigah et al. 2018). The areas estimated to be accreting by this study are locations with coastal defence structures constructed to manage coastal erosion. Angnuureng et al. (2013) and

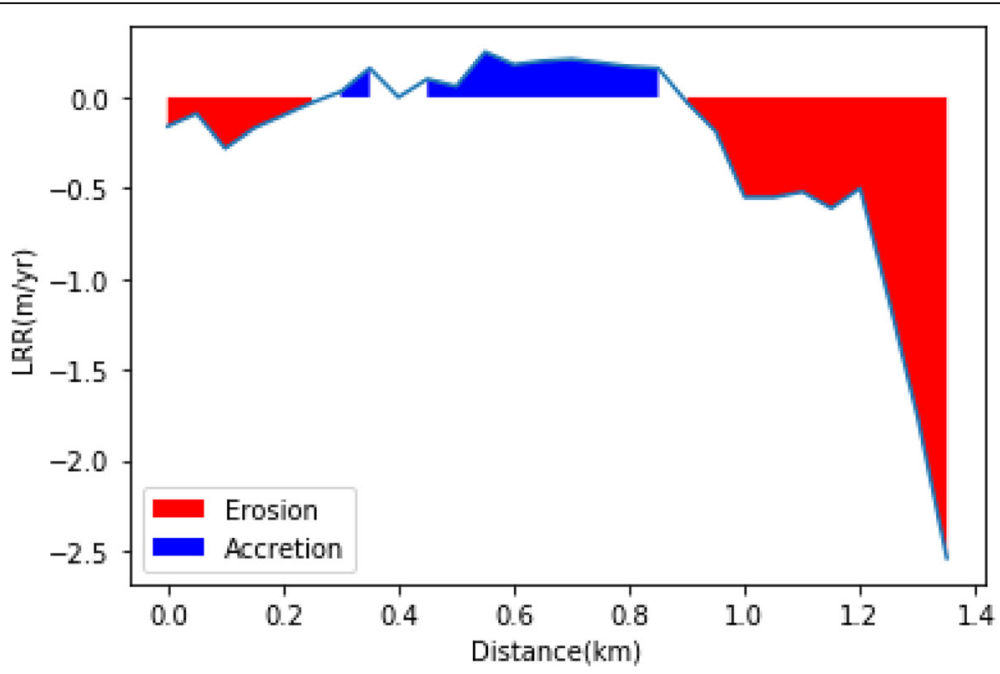

Fig. 8 Shoreline change for the western estuarine of the Volta estuary 


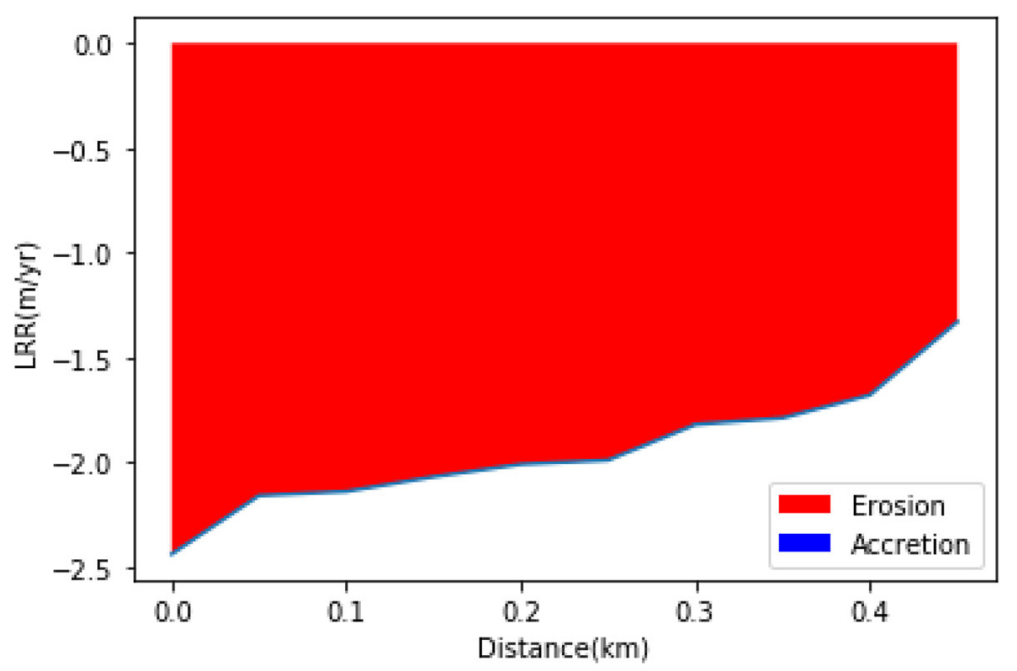

Fig. 9 Shoreline change for the eastern estuarine of the Volta estuary

Appeaning Addo (2015) reported that the Keta sea defence project has reduced the rate of erosion along the Keta coast significantly and resulted in accretion along portions of the marine coastline. This is evident in Anloga and Woe where the beaches are building up at a relatively fast rate (Appeaning Addo 2015). However, studies by Angnuureng et al. (2013) concluded that the defence structures have transferred the erosion problems downdrift of the coastline. The hard engineering methods may therefore not be the appropriate management option for erosion management along the Volta delta coast.

\section{Conclusion}

The study has revealed the erosion and accretion trend in the marine coastline and the estuarine shoreline along the Volta River in Ghana. The eastern coastline on the marine side and the estuarine shoreline are eroding more than the western coastline and shoreline. Generally, the coastline can be classified as an eroding coastline. The impact of erosion, which includes displacement of communities, loss of livelihoods and destruction of properties are expected to increase under changing climatic conditions and urbanisation This confirms studies by (Appeaning et al. 2018), where 685 people were displaced as well as 90 houses destroyed in 2011 and 2008 respectively. This will have a huge impact on both the local and national economy as the government will have to settle the displaced communities and provide adaptation options for the inhabitants. Strategies should be developed to increase resilience of the local people by developing disaster risk reduction framework for the vulnerable communities.

\section{Abbreviations}

DSAS: Digital Shoreline Analysis System; GIS: Geographical Information Systems; USGS: United States Geological Survey; DECCMA: Deltas, vulnerability and Climate Change: Migration and Adaptation;
IDRC: International Development Research Centre; DFID: Department for international Development; CARIAA: Collaborative Adaptation Research Initiative in Africa and Asia

\section{Acknowledgements}

This study was carried out under the Collaborative Adaptation Research Initiative in Africa and Asia (CARIAA), with financial support from the UK Government's Department for International Development (DFiD) and the International Development Research Centre (IDRC), Canada.

\section{Authors' contributions}

KAA designed the project, data analysis, contributed to writing and reviewing the paper. EKB did the field work, data analysis, contributed to writing and editing the paper. PNJQ contributed to the field work, data analysis, writing and editing the paper. The author(s) read and approved the final manuscript.

\section{Authors' information}

N/A

\section{Funding}

This work was supported by the International Development Research Centre (IDRC), Canada and the UK Government's Department for International Development (DFiD) as part of the Collaborative Adaptation Research Initiative in Africa and Asia (CARIAA).

\section{Availability of data and materials}

The data will be available at the University of Ghana library

Ethics approval and consent to participate N/A

Consent for publication

All the co-authors consented for the publication

\section{Competing interests}

There is no competing interest.

Received: 5 December 2019 Accepted: 7 April 2020

Published online: 25 May 2020

\section{References}

Akyeampong E (2001) Between the sea and the lagoon: an eco-social history of the Anlo of southeastern Ghana, c. 1850 to recent times

Allersma E, Tilmans WM (1993) Coastal conditions in West Africa—a review. Ocean Coast Manag 19(3):199-240 
Almar R, Kestenare E, Reyns J, Jouanno J, Anthony EJ, Laibi R, Ranasinghe R (2015) Response of the Bight of Benin (Gulf of Guinea, West Africa) coastline to anthropogenic and natural forcing, Part1: Wave climate variability and impacts on the longshore sediment transport. Cont Shelf Res 110:48-59

Angnuureng DB, Almar R, Appeaning Addo K, Senechal N, Castelle B, Laryea SW, Wiafe $G$ (2016) Video observation of waves and shoreline change on the microtidal Jamestown Beach in Ghana. In: Vila-Concejo A, Bruce E, Kennedy DM, McCarroll RJ (eds) Journal of Coastal Research Special Issue No. 75, pp 1022-1026

Angnuureng DB, Appeaning Addo K, Wiafe G (2013) Impact of sea defense structures on downdrift coasts: the case of Keta in Ghana. Acad J Environ Sci 1(6):104-121

Anim DO, Nkrumah PN, David NM (2013) A rapid overview of coastal erosion in. Ghana. 4(2):1-7

Anthony EJ (2015) Patterns of sand spit development and their management implications on deltaic, drift-aligned coasts: the cases of the Senegal and Volta River delta spits, West Africa. In: Sand and gravel spits. Springer International Publishing, Basel, pp 21-36

Anthony EJ, Almar R, Aagaard T (2016) Recent shoreline changes in the Volta River delta, West Africa: the roles of natural processes and human impacts. Afr J Aquat Sci 41(1):81-87

Appeaning AK, Nicholls RJ, Codjoe SNA, Mumuni A (2018) A biophysical and socio-economic review of the Volta Delta, Ghana. J Coast Res. https://doi. org/10.2112/JCOASTRES-D-17-00129.1 http://www.jcronline.org/doi/abs/1 0.2112/JCOASTRES-D-17-00129.1? code=cerf-site

Appeaning Addo K (2015) Monitoring sea level rise induced hazards along the coast of Accra in Ghana. Nat Hazards 78(2):1293-1307 https://doi.org/10. 1007/s11069-015-1771-1

Appeaning Addo K, Walkden M, Mills JP (2008) Detection, measurement and prediction of shoreline recession in Accra, Ghana. J Photogram Remote Sensing 63:543-558

Appeaning Addo K, Nicholls RJ, Codjoe SNA, Abu M (2018) A Biophysical and Socioeconomic Review of the Volta Delta, Ghana. J Coast Res In-Press

Armah AK (1991) Coastal erosion in Ghana: Causes, patterns, research, needs and possible solutions. In: Coastal Zone '91. ASCE, Long Beach, pp 2463-2473

Arthurton R, Korateng K, Forbes T, Snoussi M, Kitheka J, Robinson J, Monteiro P (2000) Coastal and marine environments. Environmental state-and-trends: 20year retrospective, chapter 5(2):155-191

Bio A, Bastos L, Granja H, Henriques R, Madeira S, Rodrigues D (2015) Methods for coastal monitoring and erosion risk assessment: two. Portuguese Case Stud 15(1):47-63 https://doi.org/10.5894/rgci490

Boateng I (2009). Development of Integrated Shoreline Management Planning: A Case Study of Keta, Ghana Development of Integrated Shoreline Management Planning: A Case Study of Keta, Ghana. Federation of International surveyors Working Week 2009 (TS 4E, Eilat, Isreal), pp. 3-8

Boateng I (2012) An application of GIS and coastal geomorphology for large scale assessment of coastal erosion and management: A case study of Ghana. J Coast Conserv 16(3):383-397 https://doi.org/10.1007/s11852-012-0209-0

Bollen M, Trouw K, Lerouge F, Gruwez V, Bolle A, Hoffman B, Mercelis P (2011) Design of a coastal protection scheme for Ada at the Volta-River mouth (Ghana). Coastal Eng Proc 1(32):36

Codjoe SNA, Nyamedor HF, Sward J, Dovie DB (2017) Environmental hazards and migration intentions in a coastal area in Ghana: a case of sea flooding. Popul Environ. https://doi.org/10.1007/s11111-017-0284-0

Danquah JA, Attippoe JA, Ankrah JS (2014) Assessment of residential satisfaction in the resettlement towns of the Keta Basin in Ghana. Int J Civil Engin Construc Estate Manag 2(3):26-45

Dar IA, Dar MA (2009) Prediction of Shoreline Recession Using Geospatial Technology: A Case Study of Chennai Coast, Tamil Nadu, India. J Coast Res 25(6):1276-1286

Ericson JP, Vörösmarty CJ, Dingman SL, Ward LG, Meybeck M (2006) Effective sealevel rise and deltas: causes of change and human dimension implications. Glob Planet Chang 50(1):63-82

Goussard JJ, Ducrocq M (2014) West African coastal area: Challenges and outlook In: Diop S, Barusseau JP, Descamps C (eds) The Land/Ocean Interactions in the Coastal Zone of West and Central Africa. Springer, Cham, pp 9-21

Graham D, Sault M, Bailey JC (2003) National Ocean Service Shoreline - Past, Present, and Future. J Coast Res SI(38):14-32

Ibrahim B, Wisser D, Barry B, Fowe T, Aduna A (2016) Hydrological predictions for small ungauged watersheds in the Sudanian zone of the Volta basin in West Africa. J Hydrol 4:386-397
Ile IU, Garr EQ, Ukpere WI (2014) Monitoring infrastructure policy reforms and rural poverty reduction in Ghana: the case of Keta Sea Defence Project. Mediterr J Soc Sci 5(3):633-633

Jayson-Quashigah P-N, Addo A, Kwasi BA, Wiafe G (2019) Assessment of sediment change in the Volta Delta coast in Ghana using Unmanned Aerial Vehicles (Drone) approach. Ocean Coastal Manag J https://doi.org/10.1016/j. ocecoaman.2019.104952

Jayson-Quashigah P-N, Appeaning Addo K, Kodzo KS (2013) Medium resolution satellite imagery as a tool for monitoring shoreline change. Case study of the Eastern coast of Ghana. J Coast Res Spec Is 65:511-516 https://doi.org/10. 2112/SI65-087.1

Jayson-Quashigah P-N, Appeaning Addo K, Wiafe G, Amisigo B (2018) Assessing beach volume dynamics using Unmanned Aerial Vehicles (UAVs): A Case Study of Ningo in the Volta Delta. CBAS-SDP Conefernce proceedings

Kannan R, Ramanamurthy MV, K. A. (2016) Shoreline Change Monitoring in Nellore Coast at East Coast at Pradesh District Using Remote Sensing and GIS. J Fisheries Livestock Prod 153(2):2-5 https://doi.org/10.4172/2332-2608

Karley N (2009) Flooding and physical planning in urban areas in west africa: situational analysis of accra, ghana. Theor Empirical Res Urban Manag 4(13): 25-41 Retrieved from http://www.jstor.org/stable/24872616

Leatherman SP, Whitman D, Zhang K (2005) Airborne Laser Terrain Mapping and Light Detection and Ranging. In: Schwartz ML (ed) Encyclopedia of Coastal Science, Encyclopedia of Earth Sciences Series. Springer, the Netherlands, pp 21-23

Logah FY, Amisigo AB, Obuobie E, Kankam-Yeboah K (2017) Floodplain hydrodynamic modelling of the Lower Volta River in Ghana. J Hydrol 14:1-9

Lumor, King, International Climate Change Policies (2015). Available at SSRN: https://ssrn.com/abstract=2609787 or https://doi.org/10.2139/ssrn.2609787

Ly CK (1980) The role of the Akosombo Dam on the Volta river in causing coastal erosion in central and eastern Ghana (West Africa). Mar Geol 37(3-4):323-332 https://doi.org/10.1016/0025-3227(80)90108-5

Ly CK (1981) Sources of beach sand from the central and eastern coasts of Ghana, West Africa. In: Marine Geology 44.3, pp 229-240 issn: 0025-3227. https://doi.org/10.1016/0025-3227(81)90051-7. url: http://www.sciencedirect. com/science/article/pii/0025322781900517

Mercer J, Kelman I, Taranis L, Suchet-Pearson S (2010) Framework for integrating indigenous and scientific knowledge for disaster risk reduction. Disasters 34(1):214-239 https://doi.org/10.1111/j.03613666.2009.01126.x

Morton RA, Miller TA, Moore $\amalg$ (2004) National assessment of shoreline change: Part 1: Historical shoreline changes and associated coastal land loss along the U.S. Gulf of Mexico, U.S. Geological Survey Open File Report 2004-1043, p 44 (http://pubs.usgs.gov/of/2004/1043)

Mumuni KA (2016) An Assessment Of The Effects Of The Bagre Hydro Dam Spillage On Ghana-Burkina Faso Relations (Doctoral dissertation, University of Ghana)

Nairn RB, Dibajnia M (2004) Design and Construction of a Large Headland System, Keta Sea Defence Project, West Africa. J Coast Res 33:294-314

Nairn RB, Maclntosh KJ, Hayes MO, Nai G, Anthonio SL, Valley WS (1999) Coastal erosion at Keta Lagoon, Ghana-Large scale solution to a large scale problem. Coast Eng 1998:3192-3205

Natesan U, Parthasarathy A, Vishnunath R, Kumar GEJ, Ferrer VA (2015) Monitoring Longterm Shoreline Changes along Tamil Nadu, India Using Geospatial Techniques. Aquatic Procedia 4(Icwrcoe):325-332 https://doi.org/ 10.1016/j.aqpro.2015.02.044

Nicholls RJ, Hutton CW, Lázár AN, Allan A, Adger WN, Adams H, Salehin M (2016) Integrated assessment of social and environmental sustainability dynamics in the Ganges-Brahmaputra-Meghna delta, Bangladesh. Estuar Coast Shelf Sci 183:370-381

Oguntunde P, Friesen J, van de Giesen N, Savenije HHG (2006) Hydroclimatology of the Volta River basin in West Africa:Trends and variability from 1901 to 2002. Phys Chem Earth 31(18):1180-1188

Oyedotun TDT (2014) Shoreline Geometry: DSAS as a Tool for Historical Trend Analysis. Geomorphological Techniques (Online Edition) 2:1-12

Pont D, Day JW, Hensel P, Franquet E, Torre F, Rioual P, Ibanez C, Coulet E (2002) Response scenarios for the deltaic plain of the Rhone in the face of an accelerated rate of sea-level rise with special attention to Salicornia-type environments. Estuaries 25:337-358

Rodgers C, van de Giesen N, Laube W, Vlek PL, Youkhana E (2006) The GLOWA Volta Project: A framework for water resources decision-making and scientific capacity building in a transnational West African basin. In: Integrated assessment of water resources and global change. Springer, Netherlands, pp 295-313 
Rossi G (1989) L'érosion du littoral dans le Golfe du Bénin: un exemple de perturbation d'un équilibre morphodynamique. Z Geomorphol, N F Suppl Band 73:139-165

Syvitski JP, Kettner AJ, Overeem I, Hutton EW, Hannon MT, Brakenridge GR, Nicholls RJ (2009) Sinking deltas due to human activities. Nat Geosci 2(10): 681-686 https://doi.org/10.1038/ngeo629

Thieler ER, Himmelstoss EA, Zichichi JL, Ergul A (2009) Digital Shoreline Analysis System (DSAS) version 4.0-An Ar- CGIS extension for calculating shoreline change, US Geologi- cal Survey Open File Report 2008-1278, US Geological Survey, USA

Van de Giesen N, Liebe J, Jung G (2010) Adapting to climate Change in the Volta Basin, West Africa. Curr Sci 98(8):1033-1037

van der Linden WJM, Cloetingh SAPL, Kaasschieter JPH, Vandenberghe J, van de Graaff WJE, van der Gun, J. A. M. (Eds.). (2013) Coastal lowlands: Geology and geotechnology. Springer Science \& Business Media

Van TT, Binh TT (2008) Shoreline Change Detection to Serve Sustainable Management of Coastal Zone in Cuu Long Estuaries. In: International Symposium on Geoinformatics for Spatial Infrastructure Development in Earth and Allied Sciences, pp 1-6

Wiafe G, Boateng I, Appeaning Addo K, Quashigah PN, Ababio SD, Laryea S (2013) Handbook of Coastal Processes and Management in Ghana. The Choir Press, Gloucestershire

WRC (2007) Water Resources Commission Annual Report. WRC, Accra

\section{Publisher's Note}

Springer Nature remains neutral with regard to jurisdictional claims in published maps and institutional affiliations.

\section{Submit your manuscript to a SpringerOpen ${ }^{\odot}$ journal and benefit from:}

- Convenient online submission

- Rigorous peer review

- Open access: articles freely available online

High visibility within the field

- Retaining the copyright to your article

Submit your next manuscript at $\boldsymbol{\nabla}$ springeropen.com 